\title{
Analisis Faktor Eksploratori Layanan @syariahmandiri
}

\author{
Arissetyanto Nugroho \\ Universitas Mercu Buana, Indonesia \\ arissoehardjo@mercubuana.ac.id
}

\begin{abstract}
The bank competition in Indonesia is high, conventional banks and sharia banks strive to improve competitiveness and gain positioning in the minds of the consumers. Previous research conducted by @bankmandiri compared to @syariahmandiri in 2015 gives the managerial implication that Syariah bank twitter is not as active as a conventional bank. @bankmandiri frequency compared to @syariahmandiri is different. Variety of the service proposition @ syariahmandiri is fewer than the variety of service proposition @ bankmandiri. The follow-up research is conducted by using the @syariahmandiri tweets data from January to Jul 2016. The data processed with the Provalis Research software, to obtain descriptive frequencies, hashtags, mentions and extracted name entities, cluster analysis, and to obtain the service proposition of @ syariahmandiri. The results show a robust development @ syariahmandiri twitter activities, an increasing number of tweet frequencies and varieties of service proposition compare with Jan Des 2015 dataset.
\end{abstract}

Keywords: Banking marketing strategy, bank Syariah Mandiri, @syariahmandiri, quantitativequalitative analysis.

\begin{abstract}
Abstrak: Persaingan bank di Indonesia semakin tinggi, konvensional Bank dan Bank Syariah berusaha untuk meningkatkan daya saing dan mendapatkan posisi dalam benak konsumen. Penelitian sebelumnya yang dilakukan terhadap @bankmandiri dibandingkan dengan@syariahmandiri pada tahun 2015 memberikan implikasi manajerial bahwa tweet @syariahmandiri tidak seaktif@bankmandiri. Frekuensi@bankmandiri dibandingkan dengan@syariahmandiri berbeda. Berbagai proposisi Layanan@syariahmandiri lebih sedikit variasinya dibandingkan proposisi layanan @bankmandiri. Penelitian selanjutnya dilakukan dengan menggunakan data tweets @ syariahmandiri dari Januari hingga Juli 2016. Data diproses dengan perangkat lunak Provalis, selanjutnya diperoleh frekuensi deskriptif, hashtags, mentions dan ekstraksi entitas nama, analisa cluster, dan memperoleh proposisi layanan @syariahmandiri. Hasilnya menunjukkan perkembangan yang signifikan @syariahmandiri dalam tweet berbagai kegiatannya kegiatan, peningkatan jumlah frekuensi tweet dan variasi proposisi layanan dibandingkan dengan dataset Jan Des 2015.
\end{abstract}

Kata kunci: perbankan Pemasaran strategi, bank Syariah Mandiri, @ syariahmandiri, kuantitatif kualitatif analisis.

\section{PENDAHULUAN}

Muslim menginvestasikan uang mereka dengan prinsip-prinsip Islam dan keyakinan (Devlin, 2002), yang melarang bunga/riba (Siddiqui, 2001). Islam juga melarang gharar (ketidakpastian, penipuan dan risiko), karena spekulasi, dan keterlibatan dalam bisnis yang berhubungan dengan alkohol, pornografi, atau perjudian (Khan \& Khanna, 2010). Islam percaya bahwa bunga dilarang karena tidak adil untuk mendapatkan penghasilan tanpa 
berasumsi risiko (Siddiqui, 2001), oleh karena itu perbankan Islam menyediakan layanan fundamental berbeda, dibandingkan dengan perbankan konvensional, karena kebutuhan untuk mengelola keuangan mereka tanpa riba atau bunga, layanan perbankan Syariah memenuhi kebutuhan Muslim dalam mengelola keuangannya.

Perbankan Syariah berkembang pesat di seluruh dunia, perbankan syariah adalah mode alternatif pendanaan, ketika kapitalisme juga memiliki kelemahan dalam pendanaan (Bougatef, 2015; Permana, 2017). Tingginya kompetisi antar perbankan Syariah dan perbankan konvensional juga terjadi di Indonesia (Wulandari \& Subagio, 2015). Dalam konteks Indonesia, dimana populasi lebih dari 90\% Muslim, persaingan untuk mendapatkan pelanggan antara perbankan Syariah dan perbankan konvensional menjadi sangat intens. Fenomena ini berbeda dari negara-negara lain dimana penduduk Muslim tidak sebanyak proporsi penduduk Muslim Indonesia. Di satu sisi, praktik perbankan Syariah menawarkan pemenuhan kebutuhan dalam melaksanakan dengan keyakinan Islam, tapi, di sisi lain, praktek perbankan konvensional telah memberikan berbagai layanan untuk memenuhi berbagai kebutuhan finansial nasabah.

Kompetisi antara industri perbankan dari luar negeri dan domestik juga merupakan tantangan yang meningkatkan persaingan industri perbankan di Indonesia. Di sisi lain, kebutuhan konsumen untuk berhubungan dengan pengembangan teknologi mendorong permintaan konsumen untuk pelayanan yang optimal. Semakin meningkatnya pendapatan di Indonesia, semakin menambah golongan kelas menengah, golongan ini memiliki tuntutan yang besar dalam pemenuhan kebutuhan layanan finansialnya (Chai, Tan, \& Goh, 2016).

Nasabah perbankan Syariah tidak hanya Muslim, tetapi juga non-Muslim, bahkan perbankan Syariah menjadi sebuah industri berkembang pesat (Iqbal \& Molyneux, 2016). Hal ini terjadi karena perbankan Syariah memiliki nilai yang memberikan manfaat yang berbeda, dibandingkan dengan bank konvensional. Oleh karena itu, pelanggan puas dengan pemenuhan kebutuhan mereka, keamanan tabungan di bank, dan kompatibilitas dengan mekanisme investasi Syariah perbankan (Henry \& Wilson, 2004).

Bank Mandiri dan Bank Syariah Mandiri adalah dua bank yang berbeda; yang pertama adalah bank konvensional dan yang kedua adalah bank syariah. Namun, masih sedikit penelitian tentang atribut komunikasi pemasaran bagi kedua Bank, yang mempunyai karakteristik berbeda. Dalam penelitian sebelumnya, para peneliti (Arissetyanto Nugroho \& Janfry Sihite, 2015a, 2015b, 2015 c) mengeksplorasi data dari Twitter@bankmandiri dan@syariahmandiri dari bulan Januari sampai Desember 2015. Data dibersihkan dan kemudian data diolah untuk memeperoleh atribut komunikasi pemasaran bagi kedua Bank dengan karakter yang berbeda. Hasil studi ini memungkinkan penulis untuk mengevaluasi kinerja komunikasi pemasaran dari bank dan strategi yang harus disesuaikan untuk mendapatkan kinerja yang optimal.

Penulis selanjutnya menganalisa hasil eksplorasi analisis faktor layanan atribut @bankmandiri dan @ syariahmandiri, untuk mengembangkan strategi Bank Mandiri dan Bank Syariah Mandiri (Arissetyanto Nugroho \& Janfry Sihite, 2015a, 2015b, 2015 c). Selain itu, para peneliti mempertimbangkan pilihan penelitian berikutnya untuk memperkaya temuan penelitian eksplorasi mereka diperoleh (Sihite, Harun, \& Nugroho, 2015).

Penelitian sebelumnya yang berusaha untuk mengungkapkan perbedaan dalam atribut komunikasi pemasaran layanan perbankan Syariah dibandingkan dengan Bank konvensional. Oleh karena itu, penelitian ini adalah tindak lanjut penelitian tersebut. 
Penelitian ini akan menjelajahi dataset tweet @ syariahmandiri dari Januari untuk Juli 2016 dan membandingkannya dengan hasil dari dataset @syariahmandiri dan @bankmandiri dalam periode dari Januari sampai Desember 2015.

Penelitian ini memiliki tujuan khusus untuk mengungkapkan atribut komunikasi pemasaran perbankan melalui Twitter@syariahmandiri, mengingat kurangnya penelitian yang bisa menjelaskan fenomena jaringan sosial sebagai saluran komunikasi pemasaran dan pemasaran online, produk, dan layanan perbankan di Indonesia. Hal ini sejalan dengan alasan untuk penelitian yang telah dilakukan di beberapa negara selain Indonesia.

Masih minimnya fasilitas Internet banking dan juga jaringan pendukung perbankan syariah telah mengakibatkan kecilnya minat dalam pemasaran lembaga perbankan Syariah. Perbankan syariah juga umumnya masih melihat potensi rendah dalam peran Internet sebagai media untuk menyampaikan kesadaran atau informasi kepada target konsumen potensial. Penelitian ini berusaha untuk mengembangkan keberadaan atau kepentingan dari berbagai pihak, termasuk peran teknologi, yang dapat meningkatkan perkembangan industri dan mendukung pengembangan ekonomi Islam dalam konteks jangka panjang.

Berdasarkan latar belakang ini, penelitian longitudinal mengenai atribut komunikasi pemasaran perbankan syariah melalui jejaring sosial Twitter dibutuhkan sebagai sarana komunikasi dalam proses pengambilan keputusan pemasaran. Singkatnya, penelitian ini bertujuan untuk mengungkapkan karakteristik komunikasi pemasaran perbankan syariah dari saluran komunikasi pemasaran @syariahmandiri.

\section{KAJIAN TEORI}

Konsep pertukaran didalam pemasaran menjelaskan hubungan manusia dan interaksi yang dilakukannya, mengurai alasan interaksi, serta mengukur nilai yang diterima dengan membandingkan biaya dan manfaat interaksi. Didalam setiap interaksi, manusia dihadapkan dengan berbagai pilihan, termasuk didalamnya pilihan untuk terus menjalin hubungan atau menghentikan hubungan dan mencari alternatif pilihan lainnya (Blau, 1964; Homans, 1958). Pilihan ini yang kemudian ada didalam konteks pelayanan perbankan antara perbankan konvensional dan perbankan Syariah.

Konsep pertukaran didalam pemasaran juga dapat menjelaskan pertukaran di area non komersial seperti sosial. Pernyataan ini sesuai dengan definisi pemasaran yang disampaikan oleh AMA (American Marketing Association) pada tahun 2007 yaitu "the activity, set of institutions and processes for creating, communicating, delivering, and exchanging offerings that have value for customers, clients, partners, and society at large". Definisi ini sesuai dengan "perluasan pemasaran" (marketing explanandum) (Hunt, 1983; Levy \& Kotler, 1969b) yang menggagas bahwa pemasaran bukan hanya ada di dalam area komersial, namun juga area non komersial (organisasi non bisnis). Didalam konteks penelitian ini, perbankan Syariah memiliki nilai yang berbeda dibandingkan pelayanan perbankan konvensional. Nilai riba menjadi faktor pembeda yang penting dalam konsep pertukaran konsumen perbankan Syariah.

Dasar Social Exchange Theory pertama kali diperkenalkan oleh (Homans, 1958) dalam esainya yang berjudul "Social Behavior as Exchange", didalam esai ini diajukan proposisi sebagai landasan awal dalam pengembangan Social Exchange Theory sebagai berikut: (1) Perilaku sosial adalah suatu perilaku yang mendasari pertukaran barang, bisa berbentuk materi atau immateri, seperti misalnya sebuah simbol atau perasaan gengsi. 
Seseorang yang memberi banyak akan berusaha untuk mendapatkan banyak juga, dan seseorang yang mendapat banyak akan berada dibawah tekanan untuk memberi banyak. Proses ini akan berusaha mencapai titik keseimbangan, sebagaimana keseimbangan dalam pertukaran. (2) Bagi seseorang yang berada dalam kondisi pertukaran, maka apa yang dia berikan akan dia anggap sebagai biaya dan apa yang dia dapat dianggap sebagai imbalan sehingga seseorang akan berusaha memaksimumkan imbalan yang dia dapat dibandingkan biaya yang dia korbankan (memaksimalkan laba). (3) Dia juga membandingkan dengan orang lain, dan berusaha mendapatkan laba yang terbesar dibandingkan orang lain atau jangan sampai ada orang lain yang mendapatkan laba melebihi apa yang dia dapatkan. (4) Biaya dan imbalan atau manfaat ini akan bervariasi seiring dengan berbedanya jumlah apa yang dia dapat dan apa yang dia berikan. Pertanyaannya adalah apa saja atribut-atribut yang ditawarkan oleh perbankan Syariah kepada konsumen, serta bagaimana perbedaaan atribut layanan tersebut dengan perbankan konvensional.

(Emerson, 1976) dalam (Mitchell, Cropanzano, \& Quisenberry, 2012) mengkritisi teori ini dengan menjelaskan bahwa proposisi yang diungkapkan oleh (Homans, 1958) tersebut terus dilengkapi oleh (Blau, 1964). (Emerson, 1976) menyimpulkan proposisi (Homans, 1958) sebagai berikut: (1) Success Proposition. Pada semua tindakan yang dilakukan oleh seseorang, semakin suatu tindakan diberikan imbalan, maka akan semakin suka orang itu untuk melakukan tindakan tersebut. (2) The Stimulus Proposition. Jika pada masa sebelumnya terdapat stimuli yang menyebabkan seseorang mendapatkan imbalan, dan jika pada saat ini terdapat stimuli yang serupa, maka seseorang akan melakukan tindakan yang sama atau serupa dengan masa lalu untuk mendapatkan imbalan. (3) The Depriviation-Satiation Proposition. Semakin sering seseorang mendapatkan imbalan yang sama, maka imbalan tersebut akan semakin berkurang nilainya di mata orang tersebut. (4) The Value Proposition. Semakin berharga hasil suatu tindakan bagi seseorang, semakin ingin orang itu untuk melakukan tindakan tersebut. (5) The Rationality Proposition. Dalam memilih tindakan apa yang harus dilakukan, maka seseorang akan memilih tindakan yang memberikan imbalan terbesar bagi dirinya. Didalam konteks perbankan Syariah, maka proposisi ini dapat dipetakan dengan memahami proposisi yang ditawarkan oleh perbankan Syariah.

Pentingnya citra perusahaan dalam setiap organisasi tidak bisa disangkal, begitu juga untuk perbankan Syariah (Ali, Alwi, Mokhtar, Muda, Rahim, Osman, Setapa, 2015). Perbankan Syariah harus meningkatkan kualitas layanannya, karena kualitas layanan adalah salah satu faktor-faktor keberhasilan yang penting untuk membangun citra perusahaan dan daya saing organisasi (Maswadeh, 2015). Beberapa faktor mempengaruhi perbaikan kualitas layanan, seperti efisiensi operasional, biaya operasional, pentingnya keseluruhan praktik manajemen, serta standar baru dalam efisiensi operasional dan manajemen risiko keuangan ( Rashid \& Jabeen, 2016).

Proposisi layanan perbankan telah banyak diteliti, namun proposisi layanan perbankan Syariah ini masih belum banyak diteliti. Penelitian layanan perbankan konvensional sudah dalam tahap pengukuran kualitas layanan dengan menggunakan dimensi model, seperti ketaatan, kepastian, tangibility, keandalan, responsif dan empati (Ali, Hartono \& Sudaryati, 2017; Maswadeh, 2015).

Di sisi lain, masih sangat sedikit penelitian tentang berbagai layanan perbankan Syariah. Literatur tentang layanan perbankan Syariah menyampaikan bahwa premi deposit Islam perbankan adalah $28 \%$ lebih rendah dari perbankan konvensional (Grira, Hassan, \& Soumaré, 2016). Selain itu, Riaz, Burton dan Monk (2017) menyoroti bahwa sumber daya 
yang diperlukan untuk mendukung aksesibilitas dan pengembangan produk dan layanan perbankan Syariah. SDM yang memahami konteks, sehingga mereka dapat menyampaikan pemahaman Islam kepada konsumen. Oleh karena itu, dalam konteks penelitian yang dilakukan Riaz et al. (2017), pengembangan sumber daya manusia dan pendidikan di Inggris adalah penting dan memberikan prioritas untuk dapat mencapai target membuat Inggris pusat keuangan Islam unggul layanan di dunia.

Dalam konteks persaingan antara perbankan konvensional dan perbankan Islam, atau pasar perbankan ganda, konteks karena layanan yang beragam memang nyata terjadi. Meslier, Risfandy, dan Tarazi's (2017) penelitian menunjukkan perilaku yang berbeda terjadi karena nilai-nilai berbeda antara perbankan Syariah dan perbankan konvensional. Hal ini terjadi karena perbankan konvensional sudah lebih berkembang, sehingga pasar diatur dan menyediakan layanan beragam, dibandingkan dengan perbankan Syariah.

Hal yang menarik adalah meskipun mayoritas penduduk Muslim, kekuatan pasar perbankan Syariah masih lemah. Kekuatan pasar yang kuat dalam perbankan dengan kapitalisasi besar akan mampu memberikan bunga mortgage kecil dan suku bunga deposito besar dibandingkan dengan perbankan Syariah (Meslier et al., 2017).

Bahkan penelitian Aysan, Disli, Ng dan Ozturk's penelitian (2016) menyampaikan bahwa layanan yang terkait dengan tingkat bunga mempengaruhi kelompok pelanggan dalam perbankan Islam. Dalam studi ini, para peneliti menemukan bahwa pelanggan dalam perbankan Islam lebih responsif ketika mereka tahu bahwa kesempatan yang hilang atau kerugian akibat tabungan dalam perbankan Islam adalah lebih besar daripada suku bunga di perbankan konvensional, dan mereka tidak ragu-ragu untuk menarik deposito mereka kembali.

Beberapa hasil penelitian menunjukkan bahwa layanan perbankan Syariah tidak dapat meniadakan atau mengabaikan layanan perbankan yang sudah disediakan perbankan konvensional. Masyarakat masih membandingkan manfaat yang mereka terima untuk layanan perbankan Syariah yang disediakan, meskipun karakter perbankan Syariah berdasarkan hukum Islam, yang tidak memungkinkan adanya riba. Para peneliti menyampaikan perbankan Syariah perlu mengadopsi variasi dari menawarkan layanan perbankan konvensional. Berdasarkan pemahaman ini, penelitian ini berusaha untuk melakukan eksplorasi dataset, apa layanan perbankan Syariah kepada masyarakat melalui Twitter account @syariahmandiri. Peneliti selanjutnya dapat melakukan analisis dan membangun strategi untuk meningkatkan kinerja Bank Mandiri Syariah.

\section{METODE}

Didalam penelitian ini penulis menggunakan data tidak terstruktur, khususnya data media sosial (yaitu, tweets dari Twitter @ syariahmandiri). Karena data yang dimanfaatkan adalah data tidak terstruktur, pemrosesan data diperlukan dalam mengklasifikasikan dimensi dataset. Selanjutnya peneliti menggunakan perangkat lunak Provalis untuk mengelola data tidak terstruktur dari media sosial (Devaraj, Piryani, \& Singh, 2014).

Proses mengelola data tweets dimulai dengan memperoleh data tweet. Selanjutnya data diolah lebih lanjut. Langkah ini adalah perlu karena,jika banyak data berulang kali di posting, maka bobot informasi yang sama berulang kali disampaikan lebih besar. Didalam analisis data orientasinya aadalah untuk memperoleh keragaman layanan perbankan Syariah@syariahmandiri. 
Berikut ini adalah tahapan dalam mempersiapkan data: Tahapan Pertama, dimulai dengan input deskripsi data. Proses awal input data memberikan informasi setiap jenis data. Data tweet yang diambil dari twitter @ Syariahmandiri. Tahapan Kedua, melakukan pembersihan data dan transformasi data. Proses ini dilakukan dengan perbaikan tipografi, data entri yang tidak konsisten, serta koding untuk variabel alphanumeric dan numeric, selanjutnya koding nilai kategorikal, dan akhirnya menyiapkan laporan spell checking data yang akurat.

Tahapan Ketiga, adalah stemming dan Lemmatization. Stemming merupakan proses mengelompokkan berbagai kata yang sejatinya mempunyai akar sama dengan makna sama, sedangkan lemmatization adalah proses mengelompokkan berbagai kata didalam tweet yang menyampaikan satu kata yang sama. Tahapan Keempat, adalah pembangunan kamus. Proses ini menentukan data tweet yang akan diolah lebih lanjut kedalam proses analisa dan juga data yang akan dikeluarkan dari analisa. Proses ini mengidentifikasi singkatan-singkatan maupun kepanjangan dari kata-kata didalam dataset dan menentukan terminologinya. Selain itu juga dilakukan identifikasi frasa yang umum ada didalam data, selanjutnya membangun kategorisasi awal data yang terintegrasi untuk dapat memahami kata-kata yang mungkin saja belum awam dipahami.

Teknik Analisis. Teknik analisis data dalam penelitian bagian dari exploratory factor analysis (EFA) yang sedikit berbeda dengan confirmatory factor analysis (CFA). Model rinci pada EFA menunjukkan hubungan antara variabel laten dengan variabel teramati yang tidak dispesifikkan terlebih dahulu (Wijanto, 2008). Jika didalam CFA, peneliti mencari konfirmasi dari hubungan spesifik di dalam analisa, didalam EFA peneliti tetapi membiarkan metode dan data menjelaskan sendiri hubungannya (Hair, Anderson, Tatham, \& William, 1998). Faktor-faktor diperoleh dengan mereduksi keseluruhan kompleksitas dari data dengan memanfaatkan interkorelasi dari variabel, sebagai hasilnya diperoleh faktor-faktor yang jumlahnya lebih sedikit dari jumlah variabel awal. Didalam EFA ada kemungkinan hasil yang diperoleh diluar dari literatur teori yang dipakai, oleh karena itu EFA akan mendukung pembentukan pertanyaan dengan gambaran fenomena yang nyata. Didalam penelitian ini data tweet dari twitter @ syariahmandiri digunakan untuk mengungkapkan atribut perbankan syariah (Nugroho \& Sihite, 2015a) (Nugroho \& Sihite, 2015, Nugroho \& Sihite, 2016).

Selanjutnya proses EFA dilakukan dengan teknik cluster analysis, yaitu analisis data tekstual dengan jumlah data yang banyak. Cluster analysis memudahkan peneliti untuk mengelompokkan dan selanjutnya dapat memahami berbagai tweet yang dianalisis dari akun twitter. Cluster analysis mengungkap dimensi dari berbagai tweet yang memudahkan peneliti memaknai dimensi yang tercipta (Campbell, Pitt, Parent, \& Berthon, 2011) (Arissetyanto Nugroho \& Janfry Sihite, 2015b) (Arissetyanto Nugroho \& Janfry Sihite, 2015c) (Nugroho \& Sihite, 2016).

Cluster analysis dengan QDA Miner yang terdiri dari 2 software yaitu Wordstat dan Simstat digunakan didalam penelitian ini karena menyediakan teknik eksploratori untuk mengidentifikasi kata kunci dan hubungan antara kata kunci dengan metode cooccurence (Silver \& Lewins, 2014). QDA Miner merupakan aplikasi analisis data kualitatif dengan fitur kuantitatif yang meningkatkan kemampuan peneliti untuk mengidentifikasi pola data yang penting didalam dataset. Proses koding QDA Miner dapat dimanfaatkan untuk koding kalimat maupun paragraph tekstual atau koding kata yang dapat mencerminkan konsep atau kualitas analisis tertentu. Selain juga teknik ini juga dapat digunakan untuk 
data numerik serta nilai nominal didalam kategori, numerik, Boolean dan berbagai tipe variabel lainnya (Lewis \& Maas, 2007).

Pengukuran ini menggunakan nilai tingkatan kemiripan (degree of similarity), Semakin tinggi tingkat kemiripannya elemen didalam unit analisis, semakin kecil jaraknya atau semakin mirip elemen-elemen tersebut. Disisi lain semakin rendah tingkat kemiripan elemen didalam unit analisis, semakin jauh juga jaraknya atau semakin tidak mirip elemen-elemen tersebut. Jauh dekat jarak ini dapat kita lihat di dendogram yang memberikan visualisasi antar elemen didalam unit analisis. Pengukuran ini menggunakan nilai koefisien Jaccard, nilai yang mendekati 1.0 menunjukkan bahwa semakin dekat hubungannya dengan elemen didalam unit analisis yang diobservasi (Lewis \& Maas, 2007).

Selama periode dari Januari sampai Juni 2016, peneliti memperoleh 714 tweets. Interval waktu ini diperlukan untuk mendapatkan temuan-temuan dari berbagai kegiatan perbankan Syariah. Setelah data yang bersih, kemudian proses selanjutnya adalah analisis data. Penulis melakukan analisis deskriptif untuk melihat deskripsi frekuensi tweets, deskripsi frekuensi hashtag, deskripsi frekuensi mentions, dan juga nama-nama entitas. Selanjutnya, peneliti membandingkan hasil yang diperoleh dengan kinerja @ syariahmandiri dalam periode sebelumnya.

\section{HASIL DAN PEMBAHASAN}

Hasil penelitian yang diperoleh untuk data dari Januari hingga Juni 2016 menunjukkan bahwa jumlah tweets @syariahmandiri meningkat, dibandingkan dengan periode dari Januari sampai Desember 2015. Frekuensi kata-kata dalam tweets juga berkembang, 10 frekuensi terbesar kata-kata yang ada dalam dataset periode dari Januari sampai Desember 2015 adalah, Bank Syariah Mandiri (783), sahabat (314), syariahmandiri (95), dan emas (68). Pada periode sebelumnya dengan dataset cakupan yang sama (12 bulan), frekuensinya adalah BSM (68), sahabat (35), syariahmandiri (36), dan emas (41). Frekuensi secara signifikan meningkat, hal ini menunjukkan bahwa peningkatan dalam strategi komunikasi @ syariahmandiri pemasaran telah dilakukan.

Aktivitas dalam menyampaikan berbagai atribut layanan perbankan Syariah dapat lebih lanjut dikaji dari 10 hashtags terbanyak @syariahmandiri selama periode Januari hingga Juni 2016. Hashtags gadaiemasbsm (35) dan kursbsm (34) memiliki frekuensi yang lebih besar, dibandingkan dengan hashtags yang sama dalam periode Desember tahun 2015, yaitu gadaiemasbsm (3) dan kursbsm (9). Perkembangan @syariahmandiri menunjukkan fenomena yang sama, dengan syariahmandiri (99) untuk periode data dari Januari untuk Juni 2016, yang lebih besar dibandingkan dengan syariahmandiri (37) dalam periode Januari-Desember tahun 2015.

Hal yang menarik adalah keragaman topik yang diperoleh dari proses analisa cluster data dari tweets untuk periode dari Januari sampai Juni 2016 (gambar 1). Hasilnya menunjukkan bahwa topik lebih informatif dengan memberikan kegiatan, untuk mengingatkan netizens dalam program Ramadhan dan Metro TV. Kegiatan di Metro TV menyediakan berbagai warna yang disampaikan lagi dalam Twitter @syariahmandiri, seperti undangan untuk menjalani hidup dengan menyediakan laznas (zakat), yang dapat disampaikan melalui bank Syariah Mandiri.

Pada Gambar 1 Bank Syariah Mandiri juga melakukan kegiatan IB Vaganza di Mall Bekasi. Aktivitas IB Vaganza menjadi salah satu topik yang dominan dalam analisis 
faktor-faktor. Sebagai perbankan Syariah @syariahmandiri selalu mengajak netizens melakukan salat, selain untuk mengucapkan selamat kepada netizens untuk aktivitas mereka setiap pagi. @ syariahmandiri juga memberikan layanan baru untuk Umroh atau Haji. Banyak orang setelah Umroh atau Haji kembali ke Jakarta dan masih memiliki uang riil deposit, karenanya proposisi layanan ini dikirim oleh @syariahmandiri untuk memengaruhi mereka.

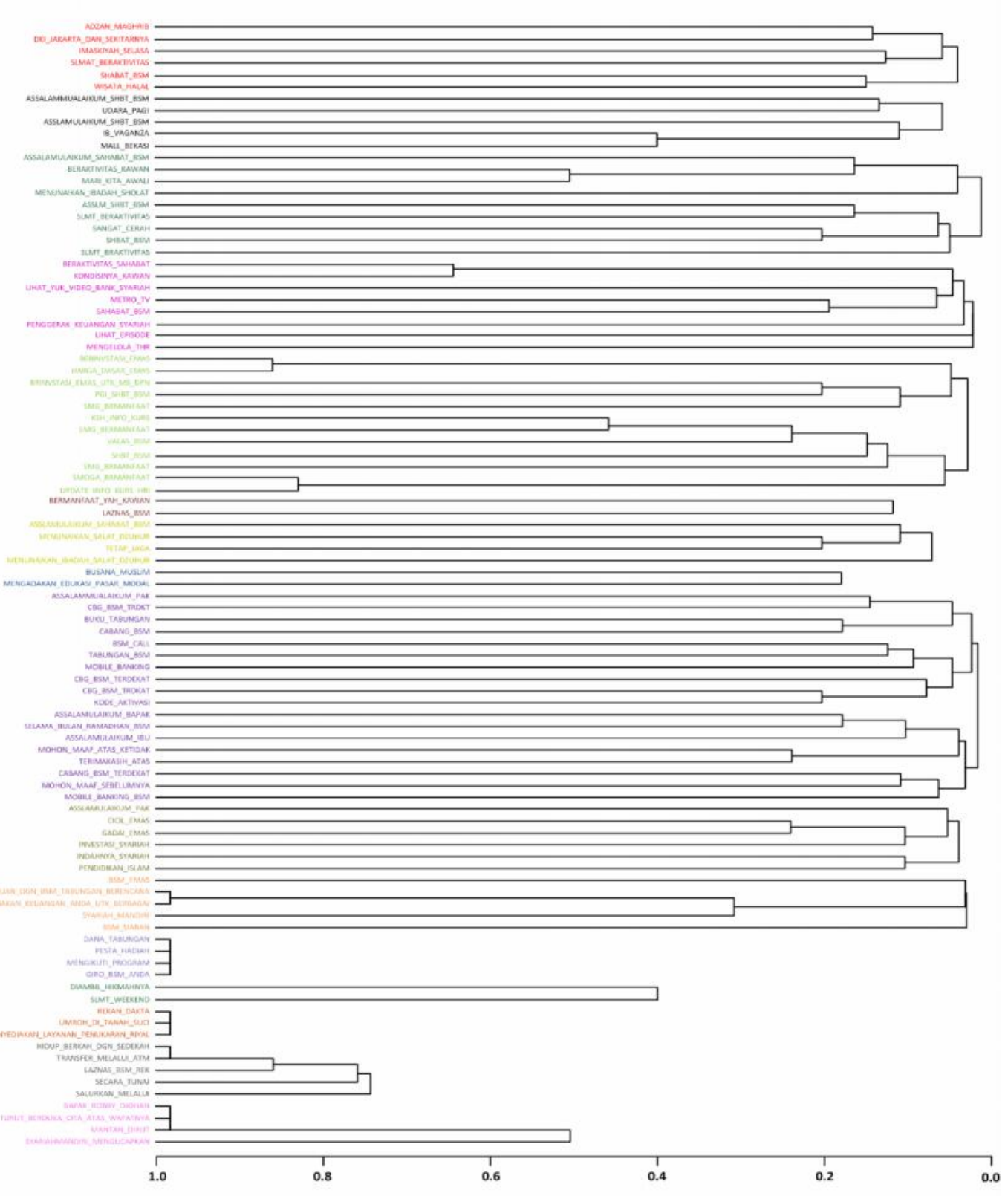

Gambar 1. @ syariahmandiri Dendogram 
@ syariahmandiri mengadakan kegiatan dengan televisi (yaitu, Metro TV). Selain itu, bank ini menyediakan rekaman dan juga informasi tentang kegiatan itu disampaikan pada @ syariahmandiri. Konsep utama dari kegiatan promosi berfokus pada konten itu diciptakan di Metro TV, tayangan juga menyampaikan ke saluran komunikasi pemasaran lainnya, salah satunya adalah Twitter. @syariahmandiri juga terus menyampaikan informasi tentang investasi emas dan nilai tukar mata uang asing, yang bermanfaat untuk klien yang ingin melakukan transaksi keuangan. @syariahmandiri juga menyampaikan program investasi emas sebagai rencana Tabungan BSM perencanaan keuangan dan perencanaan untuk klien di masa depan. Secara khusus, menawarkan layanan yang terkait dengan investasi saham yang mematuhi hukum Syariah.

Selain itu, @syariahmandiri juga menyampaikan layanan investasi dan jasa keuangan seperti layanan perbankan konvensional, yaitu tabungan dengan hadiah, dan juga layanan yang terkait dengan giro bank Syariah. Kegiatan lain bank Syariah Mandiri yaitu memberikan atau memfasilitasi zakat melalui Laznas. Aktivitas laznas dapat dilakukan dengan mudah melalui transfer melalui ATM atau tunai langsung di Mandiri bank.

Secara khusus, @syariahmandiri juga menyampaikan permintaan maaf untuk ketidaknyamanan layanan. Tweet harga dasar dan harga jual emas selama periode dari Januari sampai Juni 2016 juga banyak sebagai program yang menarik untuk sahabat BSM yang ingin berinvestasi. Ini merupakan peningkatan jika dibandingkan dengan periode Januari sampai Desember 2015, pada perode tersebut hanya informasi tentang harga jual dan beli emas yang tersedia.

\section{PENUTUP}

Rekomendasi untuk kegiatan @syariahmandiri berikutnya adalah untuk menyampaikan perbedaan manfaat dalam layanan @syariahmandiri, dibandingkan dengan layanan perbankan konvensional. Komunikasi pemasaran mereka tidak jelas menyatakan layanan @syariahmandiri dan perbedaan atribut layanannya dibandingkan dengan perbankan konvensional.

Studi ini menunjukkan bagaimana pengembangan@syariahmandiri selama periode setengah tahun terakhir telah menghasilkan peningkatan yang signifikan. Penelitian lebih lanjut akan perlu untuk mengeksplorasi bagaimana aktivitas Twitter juga menghasilkan peningkatan jumlah pelanggan dan keuntungan di bank Syariah Mandiri.

Selain itu perlu dilakukan pengematan perihal perkembangan jumlah pengikut Twitter@syariahmandiri. Jika perkembangan ini dapat dimonitor, maka kita dapat mengukur apakah peningkatan aktivitas di Twitter memberikan peningkatan pendapatan serta kesadaran produk Bank Syariah Mandiri.

Selanjutnya, hasil penelitian ini menunjukkan perlunya kegiatan perbankan Syariah memberikan pelayanan minimum yang mirip dengan perbankan konvensional dan terus mengikuti aturan-aturan yang sudah ada di hukum Islam tentang riba. Jika hal ini diterapkan, maka langkah berikutnya di masa depan penelitian berkaitan dengan keuntungan dari kegiatan perbankan Islam dibandingkan dengan perbankan konvensional perlu diuji. Itu dimungkinkan dalam konteks Indonesia, karena umumnya perbankan konvensional juga memiliki sebuah cabang dari unit bisnis perbankan Islam, sehingga mungkin untuk membedakan kegiatan dan kinerja perbankan dan melihat faktor kunci 
menjadi indikator keberhasilan Bank konvensional serta perbankan Syariah di negara dengan populasi Muslim terbesar di Indonesia. Langkah lain ke depan untuk mengetahui bagaimana cara memetakan kelompok layanan perbankan konvensional, dengan apa yang diberikan oleh grup perbankan Syariah melalui proses definisi layanan yang disediakan oleh dua jenis perbankan konvensional dan Syariah. Brand memiliki peran yang penting dalam meningkatkan performa dalam persaingan antar perusahaan. Branding merupakan faktor utama di dalam kontestasi antar perusahaan,. Branding memiliki kekuatan untuk memenangkan persaingan.

Didalam konteks industri, pada tahun 2015 McKinsey mengeluarkan laporan yang menyampaikan bahwa brand-brand kuat dunia menguasai $73 \%$ pasar, proporsi ini meningkat dari $60 \%$ pada tahun 2013. Laporan ini menyampaikan bagaimana brand-brand yang kuat memiliki kekuatan daya saing untuk mengelola performanya ditengah resesi dan krisis dibandingkan dengan brand lainnya didalam pasar. Ketika krisis, persaingan semakin tinggi karena banyak brand yang memberikan discount, beragam brand baru juga penetrasi kedalam pasar dengan meningkatkan promosinya agar memperoleh perhatian dari target sasarannya sehingga performa penjualan bagus.

Brand juga memengaruhi performa keuangan perusahaan, laporan McKinsey menyampaikan perbandingan total return to shareholder antara portofolio 40 perusahaan interbrand yang memiliki brand kuat dibandingkan dengan portfolio dari MSCI yaitu indeks pasar saham dari 1649 saham perusahaan di dunia. Hasilnya menunjukkan performa keuangan 40 perusahaan interbrand lebih tinggi sebesar $73 \%$ dibandingkan dengan MSCI.

Perbankan Syariah merupakan merek yang memiliki identitas dan potensi besar, penelitian selanjutnya perlu melakukan eksplorasi identitas perbankan Syariah, sehingga dapat membandingkan proses analisa merek perbankan Syariah dari dalam (internal) dan dari luar (eksternal), mengukur nilai merek yang melibatkan akumulasi keseluruhan nilai konsumen yang melekat pada merek tertentu, keyakinan, dan loyalitasnya terhadap merek tertentu (Aaker, 1996). Penelitian lebih dalam lagi perlu dilakukan untuk memahami identitas dari sudut pandang konsep merek, yaitu: sebelum mengetahui bagaimana kita dimaknai, kita perlu mengetahui siapa diri kita (Kapferer, 1997; Konecnik \& Go, 2008).

Selain dengan identitas merek, kita juga membutuhkan penelitian mengenai reputasi merek perbankan Syariah. Reputasi merek memiliki manfaat sebagai sinyal dari pasar dan media didalam proses menginterpretasikan informasi di pasar, sinyal kepuasan konsumen, status hirarki dan aksi di masa depan. Reputasi sebagai sinyal kepuasan konsumen dapat memengaruhi proses pembuatan keputusan khalayak sasaran lainnya seperti pesaing, rekan kerja, pekerja, investor dan pembuat keputusan (Kambara, 2010). Reputasi bermanfaat untuk mengirim sinyal suatu entitas yang tidak memiliki bentuk fisik dan sulit untuk dievaluasi kualitas serta performanya. Posisi reputasi yang kuat dan berbeda menghasilkan kemampuan untuk memberikan sinyal status hirarki (perbandingan) didalam suatu pasar dan menciptakan diferensiasi yang jelas didalam pasar. Status reputasi ini berhubungan dengan perusahaan dan tidak dapat dengan begitu saja ditiru oleh perusahaan lainnya, oleh karena itu status ini juga dapat dijaga terus oleh perusahaan agar tetap eksklusif (isolating mechanism) dan tetap menjadi keunggulan kompetitif perusahaan didalam pasar.

Merek juga mempunyai makna yang erat dengan reputasi merek karena merek menyampaikan janji, dan realisasi janji merupakan tahapan awal untuk membangun reputasi merek (Anker, Kappel, Eadie, \& Sandoe, 2012). Merek dengan reputasi memiliki 
kemungkinan besar untuk sukses dan menguntungkan karena konsumen membentuk pandangan positif terhadap merek yang dipandang kredibel. Harapan konsumen tersebut adalah realisasi janji merek berdasarkan reputasi yang sudah dimiliki. Reputasi ini diperoleh sesuai dengan pengalaman bahwa merek dapat diandalkan dalam realisasi janji (Milewicz \& Herbig, 1994).

Sebagai tahapan akhir dari penelitian perbankan Syariah, reputasi merupakan pengukuran apakah perbankan Syariah memang memiliki reputasi yang baik. Reputasi yang baik akan meningkatkan keinginan target konsumen lainnya memanfaatkan jasa perbankan Syariah, dan disisi lain jika reputasi merek perbankan Syariah kurang bagus, maka ini akan mengurangi minat target konsumen untuk menggunakan layanan perbankan Syariah.

\section{DAFTAR RUJUKAN}

Aaker, D. (1996). Building strong brands. Building Strong Brands. doi:Export Date 25 March 2014

Aysan, A. F., Disli, M., Ng, A., \& Ozturk, H. (2016). "Is small the new big? Islamic banking for SMEs in Turkey". Economic Modelling, 54, 187-194. doi:https://doi.org/10.1016/j.econmod.2015.12.031

Anker, T. B., Kappel, K., Eadie, D., \& Sandoe, P. (2012). "Fuzzy promises: explicative definitions of brand promise delivery". Marketing Theory, 12(3), 267-287. doi:10.1177/1470593112451379

Blau, P. M. (1964). Exchange and power in social life.

Bougatef, K. (2015). "The impact of corruption on the soundness of Islamic banks". Borsa Istanbul Review, 15(4), 283-295. doi:https://doi.org/10.1016/j.bir.2015.08.001

Campbell, C., Pitt, L. F., Parent, M., \& Berthon, P. (2011). "Tracking Back-Talk in Consumer-Generated Advertising: An Analysis of Two Interpretative Approaches". Journal of advertising research, 51(1), 224. doi:10.2501/jar-51-1-224-238

Chai, B. B.-H., Tan, P. S., \& Goh, T. S. (2016). "Banking Services that Influence the Bank Performance". Procedia - Social and Behavioral Sciences, 224, 401-407. doi:https://doi.org/10.1016/j.sbspro.2016.05.405

Devaraj, M., Piryani, R., \& Singh, V. K. (2014). "Data Analytics and Opinion Mining: The 'What' and 'Why' for Business Enterprises". CSI Communications. Research Front.

Devlin, J. F. (2002). "Customer knowledge and choice criteria in retail banking". Journal of Strategic Marketing, 10(4), 273-290.

Emerson, R. M. (1976). Social exchange theory. Annual review of sociology, 335-362.

Grira, J., Hassan, M. K., \& Soumaré, I. (2016). "Pricing beliefs: Empirical evidence from the implied cost of deposit insurance for Islamic banks". Economic Modelling, 55, 152-168. doi:https://doi.org/10.1016/j.econmod.2016.01.026

Hair, J. F., Anderson, R. E., Tatham, R. L., \& William, C. (1998). Black (1998), Multivariate data analysis.

Hartono, B. D., Sudaryati, E. Y., \& Ali, H. (2017). "Creating Purchase Decision of Bank Customers: Analysis of Product Quality, Place, Service Quality And Promotion (a Case Study on TAPLUS Bisnis Service of BNI Kelapa Dua Depok)". International Journal of Business and Management Invention, 6(2), 65-75. 
Henry, C. M., \& Wilson, R. (2004). The politics of Islamic finance: Edinburgh University Press Edinburgh.

Homans, G. C. (1958). "Social Behavior as Exchange". American Journal of Sociology, 63(6).

Hunt, S. D. (1983). "General Theories and the Fundamental Explananda of Marketing". Journal of marketing, 47(4).

Iqbal, M., \& Molyneux, P. (2016). Thirty years of Islamic banking: History, performance and prospects: Springer.

Khan, A. K., \& Khanna, T. (2010). Is faith a luxury for the rich? Examining the influence of religious beliefs on individual financial choices. Retrieved January, 12, 2012.

Kambara, K. M. (2010). "Managing brand instability and capital market reputation: Implications for brand governance and marketing strategy". Journal of Brand Management, 17(8), 568-578. doi:http://dx.doi.org/10.1057/bm.2010.21

Kapferer, J.-n. (1997). Strategic Brand Management. doi:Export Date 25 March 2014

Konecnik, M., \& Go, F. (2008). "Tourism destination brand identity: The case of Slovenia". Journal of Brand Management, 15(3), 177. doi:http://dx.doi.org/10.1057/palgrave.bm.2550114

Levy, S. J., \& Kotler, P. (1969b). "Broadening The Concept of Marketing". Journal of Marketing, 33, 10-15.

Lewis, R. B., \& Maas, S. M. (2007). "QDA Miner 2.0: Mixed-Model Qualitative Data Analysis Software". Field methods, 19(1), 87-108. doi:10.1177/1525822x06296589

Maswadeh, S. N. (2015). "An Evaluation of SMEs Satisfaction Toward Jordanian Islamic Banks Service Quality". Procedia Economics and Finance, 23, 86-94. doi:https://doi.org/10.1016/S2212-5671(15)00463-3

Meslier, C., Risfandy, T., \& Tarazi, A. (2017). "Dual market competition and deposit rate setting in Islamic and conventional banks". Economic Modelling, 63, 318-333. doi:https://doi.org/10.1016/j.econmod.2017.02.013

Milewicz, J., \& Herbig, P. (1994). "Evaluating the brand extension decision using a model of reputation building". Journal of Product \& Brand Management, 3(1), 39-47.

Mitchell, M., Cropanzano, R., \& Quisenberry, D. (2012). Social Exchange Theory, Exchange Resources, and Interpersonal Relationships: A Modest Resolution of Theoretical Difficulties. In

Nugroho, A., \& Sihite, J. (2015). Tweeting And Retweeting Tourism And Airline Service Attributes. Thomson Reuter Indexed Proceeding. International Geographical Union \& Lombok International Conference. University Mataram.

Nugroho, A., \& Sihite, J. (2015a). "Does The Social Network Relate With The Entrepreneurship? An Empirical Content Analysis". Manajemen, XIX(2).

Nugroho, A., \& Sihite, J. (2015b). "Is It A Relational Marketing Strategy? Cluster Analysis@Universitasmercubuanajakarta Facebook Post and Comment". Manajemen MIX, V(2).

Nugroho, A., \& Sihite, J. (2015c). "Is It Traditional or Contemporary Marketing Strategy? A Textual Cluster Analysis @MercuBuana_Reg". Mediterranean Journal of Social Sciences, VI(5).

Nugroho, A., \& Sihite, J. (2016). Exploratory Factor Analysis Syariahmandiri and Bankmandiri Service Attributes 2015. The Social Sciences, 11, 4896-4901.

Osman, I., Alwi, S. F. S., Mokhtar, I., Ali, H., Setapa, F., Muda, R., \& Rahim, A. R. A. (2015). "Integrating Institutional Theory in Determining Corporate Image of Islamic 
Banks". Procedia - Social and Behavioral Sciences, 211, 560-567. doi:https://doi.org/10.1016/j.sbspro.2015.11.074

Permana, D. (2017). "Examining Internal Mechanism Corporate Governance on Indonesian Islamic Banking Performance". Journal of Resources Development and Management, 34(1-9).

Rashid, A., \& Jabeen, S. (2016). "Analyzing performance determinants: Conventional versus Islamic Banks in Pakistan". Borsa Istanbul Review, 16(2), 92-107. doi:https://doi.org/10.1016/j.bir.2016.03.002

Riaz, U., Burton, B., \& Monk, L. (2017). Perceptions on the accessibility of Islamic banking in the UK-Challenges, opportunities and divergence in opinion. Accounting Forum, 41(4), 353-374. doi:https://doi.org/10.1016/j.accfor.2017.10.002

Siddiqui, S. H. (2001). Islamic banking: true modes of financing. New Horizon, 109, $15-$ 20.

Sihite, J., Harun, T. W., \& Nugroho, A. (2015). "The Low Cost Airline Consumer Price Sensitivity. An Investigation on The Mediating Role of Promotion and Trust in Brand". International Research Journal of Business Studies, VII(3).

Silver, C., \& Lewins, A. (2014). Using software in qualitative research: a step-by-step guide.

Törnblom, K \& Kazemi, A (Eds.), Handbook of Social Resource Theory (pp. 99-118): Springer New York.

Wijanto, S. H. (2008). Structural Equation Modeling dengan LISREL 8.8: Konsep dan Tutorial.

Wulandari, D., \& Subagio, A. (2015). Consumer Decision Making in Conventional Banks and Islamic Bank based on Quality of Service Perception. Procedia - Social and Behavioral Sciences, 211, 471-475. doi:https://doi.org/10.1016/j.sbspro.2015.11.062 